\title{
Beyond the Battlefields of Memory: Historical Traumas and Hungarian Literature
}

The aim of this essay is to outline some strategies of representing the past in Hungarian narrative fiction after the 200os. My basic premise is that some tendencies of Hungarian literature can be described as forms of memory or, more precisely, as methods or strategies that both represent and shape the collective memory of society. In the following, I focus only on those trends, tendencies and authors representing the rich texture of contemporary Hungarian literature that seem to be important from this memory-centered viewpoint.

At first, I will distinguish two versions of recent attitudes to the past or more closely to some significant historical events of the twentieth century in Hungary. These approaches can be described with terms developed by Michael Rothberg (2009), who has distinguished two possible forms of remembering and representing traumatic events of the recent past, calling them competitive and multidirectional memory. While the first interprets the act of remembering and the ground of collective memory as a kind of battlefield where some type of remembrances and some kind of past events need to be highlighted and others to be repressed, the second understands the various traumatic events as a kind of network in which the memories of some happenings do not repress others but help to shape appropriate remembrance strategies to them. I will argue that these types of memory have some political implications, and certain literary forms and strategies can be connected closely to these political viewpoints. Finally, I will analyze some narrative and thematic aspects of literary works pre- 
senting certain traumatic events of the twentieth century. After the postmodern metafictional trend, a significant wave of new realism appeared in Hungarian literature in the past two decades. One can understand better the cultural and political causes and consequences of this "realist turn" by analyzing different strategies of remembering the past in contemporary literature.

\section{Collective Remembrance in Hungary After 1989}

The history of Hungarian collective remembrance appears to be a battle of interpretations of traumatic historical events of the twentieth century. I use the term 'traumatic event' in the sense of Jeffrey C. Alexander's model of socially constructed trauma emphasizing that these events are not a priori traumatic but are fashioned and interpreted by a given society as significant, shocking, and disastrous. Thus, constructing a cultural trauma is a significant act of collective self-understanding, since a society creates a special attitude to the given historical event by which it interprets its present situation. According to Alexander,

[e]vents are one thing; representations of these events are quite another. Trauma is not the result of a group experiencing pain. It is the result of this acute discomfort entering into the core of collectivity's sense of its own identity. Collective actors 'decide' to represent social pain as a fundamental threat to their sense of who they are, where they came from, and where they want to go. (Alexander 15)

Consequently, traumatic events are shaped by collective remembering, and certain cultural factors, especially art and literature, have a distinguished role in constructing them.

The historical events in Hungarian collective memory that can be called traumatic in this sense include the following: the peace treaty of Trianon in 1920, when the Hungarian state, defeated in WWI, lost the two thirds of its historical territories; the Hungarian Holocaust in which about six hundred thousand Hungarian Jews and gypsies were executed; the occupation of the state by the Soviet Army in 1945; the communist dictatorship; and the suppression of the Hungarian revolution in 1956. Of course, memories of these events labeled traumatic have been constructed in various ways, but all of them were more or less suppressed during state socialism. ${ }^{1}$ After the regime change in 1989,

1 Some recent historians started to challenge the "myth of silence" of Holocaust discourse in the socialist period, emphasizing that instead of the total suppression 
the modes of remembrance of these events were conditioned by political attitudes and deeply politicized interpretations of the Hungarian history. In general, one can distinguish two basic directions dealing with traumatic events that are considered symbolic. The first, a mostly right-wing narrative placed Trianon in the focus of Hungarian history which was understood as a victim story of a "glorious nation" that was mortally wounded, firstly by Western European states who decided to truncate the body of the country and later by a Sovietized regime that repressed and terrorized Hungarian people (see Feischmidt 2014; Kovács 2015). Such nationalist interpretations of Hungarian history usually did not include the Hungarian Holocaust as a traumatic event, or if they did then its role in the metanarrative was subordinate and negligible. The second, leftist or liberal type of narrative represented twentieth Hungarian history as a story of victims and perpetrators as well, but it focused mostly on the Holocaust and the atrocities of a socialist regime. The importance of Trianon was less stressed in this narrative, mostly because its commemorative practices and symbols were monopolized by the first, right-wing strategy of remembrance. The memory of the socialist period became significant for both directions but with a different level of significance. While the first, right-wing narrative underlined primarily the foreign suppression of the nation, the second focused basically on the atrocities against human rights and freedom.

It should be emphasized that these two strategies function here mostly as ideal types, since their history and discursive operations are much more complex. But in general, the strategies of collective memory in Hungarian discourse after 1989 can be considered as characteristically competitive. The competitive memory, as Rothberg pointed out, functions as a kind of zero-sum game where different memorial communities build up their own identity by marking some past events as substantial, and by emphasizing the significance of remembering these events. As he stressed:

Fundamental the conception of competitive memory is a notion of the public sphere as a pregiven, limited space in which already-established groups engage in a life-and-death struggle.... As I struggle to achieve recognition of my memories and my identity, I necessarily exclude the memories and identities of others. (Rothberg 2009: 5)

certain patterns of interpretation and representation were used in connection with the Holocaust. See in more details the essays by Tamás Scheibner, Máté Zombory, Richard B. Esbenhade, Tímea Jablonczay, and Balázs Varga in Múltunk, 15. (2019). 
In other words, competitive memory needs to identify some events as exclusive and thus other events that might be similarly significant for a different group are overshadowed. This strategy often focus on questions like "why does one represent or commemorate the Holocaust, and why not other atrocities, which, according to this opinion, are fundamentally underrepresented?" Such a mindset treats acts of commemorating the Holocaust equivalent to rendering other traumatic events into oblivion (e.g. Trianon or the mass murders of communism).

Competitive memory with its (in Bakhtin's terms) monological and explicitly political attitude cannot be effectively served by literary representations that are multilayered and complex. It does not mean that certain literary works would have a priori competitive or monological character. Rather, this competition-based memory politics has a kind of interpretative attitude that helps to select its authors, works and literary canon, read them in monological ways and exclude other possible understandings of the texts and the past in general. In Hungary, the current right-wing literary canon has been transformed radically in the last two decades. After the 200os, it came to highlight authors from the 1930 s and 1940 s instead of contemporary writers or authors from the recent past. Writers like Albert Wass, József Nyírő or Cécile Tormay have been interpreted as representing a romanticized vision of a unified country and nation before the Trianon peace treaty or a nostalgic view of the lost unity and greatness. The literary significance of these authors is varied. They were banned in the socialist period mostly due to their nationalist (or sometimes anti-Semitic or proto-fascist) views, but their importance has gradually grown mostly because one can easily connect to their works a nostalgic view on the nation's past greatness, which was destroyed by the division of the state after the Trianon treaty. This strategy of memory can be described with Svetlana Boym's term as retroactive nostalgia that "does not think of itself as nostalgia, but rather as truth and tradition," and its main aim is "a transhistorical reconstruction of the lost home" (Boym 2001, xviii). Thus, memory strategies supported by the nostalgic literary canon of this discourse depict the Hungarian history in twentieth century as a kind of "paradise lost"-story. However, some traumatic events are not compatible with this narrative, especially the Hungarian Holocaust in which citizens of the nation were deported by other Hungarian citizens. Consequently, these events are necessarily regarded as competitors and potential opponents of their "adequate" strategy of memory.

The aim of this very brief (and unavoidably simplified) survey was to show the background from which another form of memory, represented by contemporary literature, crystallized. However, an analysis of recent trends in literature 
with stakes in memory politics requires a glance at the literary representation of history before the millennium in Hungary.

\section{From Text to Context, or New Directions of the Hungarian Historical Fiction After 2000}

The historical fiction in Hungarian literature regained currency in the 1990s. It has been regarded by critics as a second wave of the so-called "prose turn" (prózafordulat) of Hungarian fiction, a trend that emerged in the 1970 s and was linked predominantly to the influential writer, Péter Esterházy. According to the critical consensus, this turn, associated with the emergence of a supposed Hungarian postmodernism, renewed the Hungarian fiction by keeping distance of the "real" or "historical" world and challenging such concepts (see Kulcsár Szabó 1993). Emphasizing the language oriented, intertextual and self-centered character of postmodernism was a political act in itself in the 1980s, when official Marxist literary criticism favored realism over any other approach. The historical fiction in the 1990s-represented mostly by the second generation of Hungarian postmodernism (László Márton, László Darvasi, János Háy, Zsolt Láng)—can be compared with the so-called 'historiographical metafiction' of Western literature (see Hutcheon 1988). These writers hardly ever represented twentieth century events, but usually depicted the sixteenth to eighteenth centuries in a manner reminiscent of nineteenth century Hungarian classic historical novels. This afforded them better opportunities to reflect the textual and linguistically conditioned character of historical knowledge.

There were two significant literary events in the early 2000 s that can be considered as symbolic from our viewpoint. Both were connected to the traumatic historical events of twentieth-century Hungarian history. Péter Esterházy's Javitott kiadás (Corrected Version) (2002) was often considered as a continuation of his 2oo1magnum opus, Harmonia caelestis (Celestial Harmonies). This latter novel is arguably a culminating (or end-)point of Hungarian postmodern fiction that surveys centuries of Hungarian history and the narrator's personal family story with a multiplied figure of a metaphorical "father" in the center. Corrected Version, in contrast, focuses on more personal stories of the author/ narrator. When the writer Esterházy had been working on the Celestial Harmonies and did research in archives on his family, he realized that his (real) father was a secret agent and informer in the socialist period. Thus, the second novel connects personal traumas to historical ones and introduces to the Hungarian cultural discourse an important problem of the fathers' generation involvement in the socialist dictatorship. The same year Corrected Version appeared, Imre 
Kertész won the Nobel Prize. His masterpiece Sorstalanság (Fateless) (1975) represented the Holocaust from a viewpoint of a teenage boy. Although Kertész's work had already been known by literary critics, the wider public became acquainted with them only after the prize. Both events received great attention by the press and contributed to the start of a wider public debate on chapters in the recent past of Hungary that were by many regarded as uncomfortable. Such debates, however, relatively quickly had to face an abrupt end, as the earlier mentioned competitive character of Hungarian collective memory polarized sides and prevented society-wide reflection. The competitive memory was set to work on both political sides, even though there was a difference of degrees. For example, winning the Noble Prize created a scandal on the far-right, and politicians and publicists emphasized that there were much more important topics and traumas of Hungarian history than the Holocaust. In the leftist and liberal press, a smaller scale dispute emerged that also presented traits of competitive memory: when Kertész stated that his novel metaphorically reflects state socialism as much as Nazism and hinted at the role of ordinary people in dictatorships, some critics raised their voice against such a view and considered the Holocaust-centered reading as the sole adequate opinion (see also Royer 2017, 322-327).

One may consider these events as symptoms of a literary and social process in which the cultural function of literature and the stake of representation of some historical events of recent past increased. After the early 200os, more and more novels were published in Hungary on traumatic events in history or on some longer processes of the recent past. I would highlight two significant directions in fiction here without any claim for exclusivity: two trends that are interlinked with each other.

First, one can single out a series of literary works that present traumatic events of Hungarian history, whose memory was suppressed or silenced in earlier periods. Even though such sensitive issues as the Hungarian role in the history of the Holocaust, the historical dimensions of the 1940s, or the role of ordinary people in Nazi and communist dictatorships have occasionally been on the agenda in the public sphere in the past decades, these disputes took place rarely and were scattered. In Hungary, Historikerstreit-type exchanges were not held, instead, simplified narratives and explanations dominated public discourse, including museum spaces or memorials. This simplification has worked on two levels. Firstly, one of the main strategies has been to create a more or less unified narrative of victimization, where both the Holocaust and the socialist period were narrated as tragic stories of the nation conquered by an alien power. A remarkable example of this tendency is the officially erected 
monument of the German occupation (2014), the iconography of which refers directly to this kind of victim narrative: the nation symbolized by an angel figure is attacked by an eagle, the allegorical representation of the Nazi Germany (see also Horváth 2014). The other tendency, linked closely to the first, is also a unifying strategy that emphasizes the similarity of the Nazi and the socialist periods from a simplified interpretation of totalitarianism. It is represented by the conception of the Budapest House of Terror that declared itself a museum of the Nazi and the communist regimes' victims, but it is hardly more than a spectacular, multimedial representation of the continuity and similarity of two dictatorships (see also Apor 2014). However, one can notice that these two strategies are means to the aim of "competitive victimization" (Rothberg 2009: 313), since they emphasize the unified character of the regimes and usually represent the Holocaust as a relatively short stage of a collective passion story. Sometimes the contemporary governmental strategy to define the literary canon serves also this goal. The digital legacy of Imre Kertész, for instance, was acquired by an institute directed by the outspokenly pro-government historian, Mária Schmidt, who also serves as the manager of the House of Terror. The officially propagated interpretation of Kertész's oeuvre aims to monopolize the memory of the author and legitimize the regime's conception of totalitarianism by the writer's authority.

Given such aspirations, a closing public sphere and increasing political pressure on the press, it seems that literature might regain a significant role in addressing complicated or traumatic historical issues. A common feature of new literary works that choose their topic from this realm is that they emphasize not a collective, social or class-oriented experience like classic historical or realist novels, but concentrate on the personal level and try to present the individual situations and subjective viewpoints of the past. One can connect this strategy to some relatively new historiographical directions which appeared in Hungarian historical discipline after the 1990s, such as oral history and microhistory. No coincidence that some of the authors in the 2000 came from social sciences. For example, Pál Závada is a sociologist and his novels almost systematically present some important but basically underrepresented or suppressed periods and events of Hungarian history. His books, including Idegen testünk (Our Foreign Body) (2008) and Természetes fény (Natural Light) (2014), show the personal experiences of ordinary people from different cultural, social and racial background before, during and after the Second World War by voices of multiplied narrators. Another book, Egy piaci nap (A Market Day) (2016), narrates a relatively forgotten, shameful event of Hungarian history, an anti-Jewish pogrom that occurred in a Hungarian large-village, Kunmadaras 
in May 1946. Judit Kovács came from social sciences as well, she is actually an oral historian, and her novels, Megtagadva (Denied) (2012), Elszakitva (Detached) (2015), and Hazátlanok (Homelesses) (2019), were crystallized from personal accounts of women who actually lived through similar tragic events after the war. ${ }^{2}$ A widely discussed novel with captivating imagery and scenes was Orgia (Orgy) (2016) by Gábor Zoltán; it represented one of the most brutal months of Hungarian history: the period when the Hungarian Nazis, the Arrow Cross Party, took power. The story is set in Budapest at the end of December 1944, and it narrates how ordinary people become implicated in the most cruel rapes, tortures and massacres. The novel got mixed reviews mostly due to its graphic violence that, according to some critics, transformed the actual historical situation into a horror-like dance macabre but the Orgy undoubtedly initiates an important debate about an underrepresented topic.

The increasing interest in everyday life under dictatorship rule is a clear trend in recent Hungarian fiction. One of the most important and internationally successful authors of the middle generation, the Târgu Mureș-born György Dragomán's two novels, A fehér király (The White King) (2005) and Máglya (The Bone Fire) (2014), presents the Romanian communist period from the viewpoints of child protagonists. The novels describe not only the actual historical situations (the first is about the 1980s and the second concentrates on the aftermath of the Romanian revolution), but represent a general, metaphorical state of how to grow up in a dictatorship or, more universally, in a world that is fundamentally based on violence and oppression. Krisztina Tóth's novel the Akvárium (Aquarium) (2013) similarly represents a plethora of personal life stories and viewpoints and narrates daily experiences of Hungarian socialism through the story of a family, with the shadow of Holocaust in the distant background. A larger scale family story is Imre Oravecz's trilogy A rög gyermekei (Children of the Clod) (2007-2018) that follows and continues the earlier mentioned sociographic tradition telling the story of a peasant family from the middle of the nineteenth century to 1956 .

The novels of Andrea Tompa, Fejtöl s lábtól: Kettö orvos Erdélyben (From Head and from Leg: Two Doctors in Transylvania) (2013) and Omerta: Hallgatások könyve (Omerta: Book of Silences) (2017), depict the life of the Transylvanian Hungarian minorities after Trianon, and deserve special mention, for these are interesting attempts at representing the traumatic event of Trianon

2 It is important to mention that there is a long tradition of sociographic and anthropological semi-literary accounts of peasants and workers that started in 1930 and relived in 1970s. Závada can be connected primarily to this tradition. 
without the earlier mentioned idealizing narrative strategies. From Head and from Leg is about the period between the two world wars from the viewpoints of two narrators, a male and female physician whose personal lives are closely connected to the history of Hungary and Romania. The other novel, Omerta, tells the history of Kolozsvár/Cluj-Napoca in the 1950 os by four narrators with different social statuses and gender positions-a Szekler peasant woman, an intellectual man, a middle-class bourgeois woman, and a nun. Through their voices a variety of possibilities emerge by which Hungarian minorities in Romania could live during a communist dictatorship. Individual responses to great political events and state oppression are not represented as part of any wide-scale historical perspective or grandiose allegory; instead, the choices and hardships of minority persons are handled on a personal level.

\section{Conclusion: Towards a Multidirectional Conception of Memory}

No doubt, the novels mentioned above are just a few examples reflecting my personal taste in the absence of critical consensus, but it still allows us to draw two basic conclusions that I think remain valid for the entire contemporary Hungarian literary culture. Firstly, it seems that after the postmodernist turn of the late-twentieth century, Hungarian literature has been turning towards a direction that favors more mimetic narrative techniques and documentative historicism. Also, literary works increasingly have social stakes. Some critics call this a realist turn but, according to them, this "realism" means not a simple return to the "old," nineteenth style methods of representation but a style that incorporates and reflects experiences of postmodernism, minimalism and literary trends of the recent past with strong social emphases (see Takáts 2019). This tendency also manifests itself in another important literary topic or direction that represents the outcasts and the destitute of our society, people whose voices were repressed till now. The authors of this trend (Szilárd Borbély, Tibor Noé Kiss, László Szilasi, Edina Szvoren, etc.) followed partly the sociographic movement of Hungarian literature, and their novels sometimes depict some historical traumas as well. The most spectacular example is Szilárd Borbély's very influential novel, the Nincstelenek (The Dispossessed) (2013), concentrating on the life of some inhabitants in a poor Hungarian village, and, through the voice of a child narrator, the question of Jewishness becomes one of the most important problems. Therefore, narrating traumatic historical events can join the tendency of representing poor people who were hardly present in recent literature and in public discourse. Thus, this post-postmodern new realism has a moral ambition to discuss some barely disputed questions of society. 
We have seen that competitive memory defines public discourse, and various literary trends are subverting it. These tendencies in contemporary Hungarian fiction could be linked to another strategy of memory suggested by Rothberg: multidirectional memory. This is a model of collective memory of traumatic events that is not necessarily competitive, that considers diverse remembrances of different groups not as a "zero-sum game"-type battle but as a network where the memory of one event can reinforce other ones, creating a dialogue among these groups and memories. In the Hungarian literary field the multidirectional conception of memory can operate on thematic and narrative levels as well. These novels represent some traumatic events and aspects of the past from Trianon through the Holocaust to the socialist period with a strong moral commitment attached to their new realist style. By dialogical representation of some personal views of the past, these works can challenge some generally established or officially asserted preconceptions (e.g. sharp lines can separate the victims, perpetrators and bystanders) and induce wider social debates about these historical occurrences. Undoubtedly, these social debates are only partial now, at best, and there is almost no dialogue between what we may call representatives of competitive and multidirectional memories. The fact that more and more literary works perform the task of starting significant historical and cultural debates in Hungary, however, renders such dialogue harder to avoid day-by-day.

\section{| References}

Alexander, Jeffrey C. Trauma. A Social Theory. Cambridge: Polity Press, 2012. Apor, Péter. "An Epistemology of the Spectacle? Arcane Knowledge, Memory and Evidence in the Budapest House of Terror." Rethinking History 18 (2014): 328-344.

Boym, Svetlana. The Future of Nostalgia. New York: Basic Books, 2001.

Feischmidt, Margit. "Populáris emlékezetpolitikák és az újnacionalizmus: a Trianon-kultusz Magyarországon." (Popular Memory Policies and the New Nationalism: the Cult of Trianon in Hungary.) Ed. Margit Feischmidt.. Nemzet a mindennapokban: az újnacionalizmus populáris kultúrája. Budapest: L'Harmattan, 2014. 51-81.

Horváth, Sándor. "Goodbye Historikerstreit, Hello Budapest City of Angels; The Debate about the Monument to the German Occupation." Cultures of History Forum, https://doi.org/10.25626/0037. Accessed 4 December 2015. 
Hutcheon, Linda. A Poetics of Postmodernism. History, Theory, Fiction. London and New York, Routledge, 1988.

Kovács, Éva. “Trianon, avagy a 'traumatikus fordulat' a magyar történetírásban.” (Trianon, or the 'Traumatic Turn' in Hungarian Historiography). Korall 59 (2015): 82-107.

Kulcsár Szabó, Ernő. A Magyar irodalom története 1945-1991. (The History of Hungarian Literature 1945-1991.) Budapest: Akadémiai, 1993.

Rothberg, Michael. Multidirectional Memory. Remembering the Holocaust in the Age of Decolonialization. Stanford, California: Stanford UP, 2009.

Royer, Clara. Imre Kertész: "L'histoire de mes morts." Arles: Actes Sud, 2017.

Takáts, József. "Az inga visszaleng - Elbeszélő próza a kétezres években." (The Pendulum Swings Back: Narratives After Millenium). Helikon 59 (2018): 336-347.

\section{| Abstrakt}

TAMÁs KisAnTAL

Poza pobojowiskami pamięci. Historyczne traumy i literatura węgierska

Współczesną węgierską pamięć zbiorową można opisać jako pole interpretacyjne kilku traumatycznych wydarzeń historycznych xx w. Artykuł ma na celu wskazanie ważnych tendencji w reprezentacji literackiej tych wydarzeń w nowym tysiącleciu. Na początku autor szkicuje konteksty społeczne i polityczne utworów literackich. Następnie przedstawia współczesną kulturę węgierską jako przeciwieństwo dwóch strategii pamięci, posługując się terminologią Michaela Rothberga - rywalizacyjnej i wielokierunkowej. Takie podejście do przeszłości wiąże się z różnymi implikacjami ideologicznymi, jak również kanonami literackimi. Wreszcie, wraz ze wskazaniem wybranych najnowszych powieści, autor pokazuje kilka sposobów reprezentacji wielokierunkowego podejścia do przeszłości w węgierskiej literackiej prozie nowego tysiąclecia.

Słowa kluczowe: pamięć kolektywna; wydarzenia traumatyczne; pamięć rywalizująca i wielokierunkowa; współczesna proza historyczna; nowy realizm 


\section{| Abstract}

TAMÁs KisAnTAL

\section{Beyond the Battlefields of Memory: Historical Traumas and Hungarian Literature}

One can describe the contemporary Hungarian collective memory as an interpretational field of some traumatic historical events of the twentieth century. The essay aims to sketch some important tendencies of the literary representation of these events after the millennium. At first, it outlines the wider social and political contexts of these literary works. Secondly, it models the current Hungarian cultural field as an opposition between two strategies of memory labeling them in Michael Rothberg's terminology as competitive and multidirectional ones. These approaches to the past are also associated with different ideological implications and literary canons. Finally, with a brief overview of some recent novels, the essay demonstrates some pathways of representing multidirectional attitudes to the past in the Hungarian literary fiction of the 2000 .

Keywords: collective memory; traumatic events; competitive and multidirectional memory; contemporary historical fiction; new realism

\section{| About the Author}

Tamás Kisantal is an associate professor at the University of Pécs, Institute of Hungarian Language and Literature, Hungary. His main fields include narrative problems of historiography, contemporary theories of history, and literary representation of the Holocaust. He is an author of three books, more than 150 essays and reviews, and editor of seven volumes. His next monograph on representational strategies of the Holocaust in the postwar Hungarian literary discourse will be published soon. E-mail: kisantal.tamas@pte.hu 